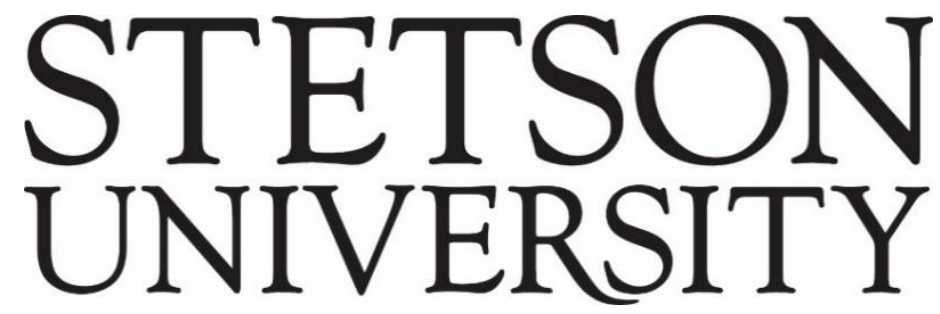

Voices of Reform: Educational Research to Inform and Reform

Volume $1 \bullet$ Issue $1 \bullet$ Article 6

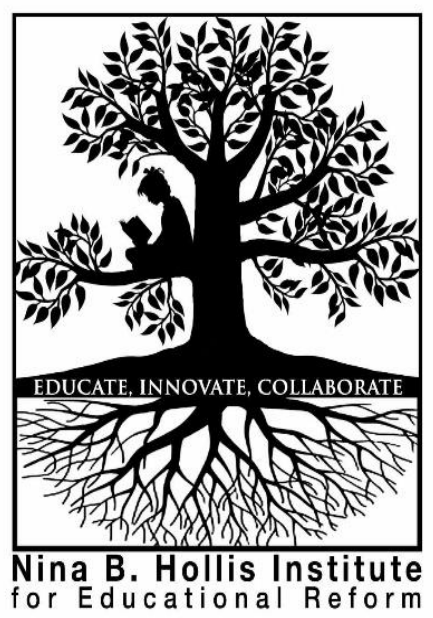

September 2018

Reframing Education Finance: Super

Wickedness, Silver Bullets, and Educational

Inheritance

Maureen W. McClure

University of Pittsburgh

Follow this and additional works at: http://www.voicesofreform.com

Recommended Citation

McClure, M. W. (2018). Reframing education finance: Super wickedness, silver bullets, and educational inheritance. Voices of Reform, 1(1), 91-98. Retrieved from https://www.voicesofreform.com/article/4455-

reframing-education-finance-super-wickedness-silver-bullets-and-educational-inheritance. doi: 10.32623/1.00008

http://dx.doi.org/10.32623/1.00008

Revisions

Submission date: May $31^{\text {st }}, 2018$

$1^{\text {st }}$ Revision: July $31^{\text {st }}, 2018$

Acceptance: August $30^{\text {th }}, 2018$

Publication date: September $15^{\text {th }}, 2018$

Grammatical Revision date (online only): May $28^{\text {th }}, 2019$ 


\title{
Reframing Education Finance: Super Wickedness, Silver Bullets, and Educational Inheritance
}

\author{
Maureen W. McClure ${ }^{1}$ \\ ${ }^{1}$ Department of Administrative and Policy Studies \\ University of Pittsburgh, United States \\ mmcclure@pitt.edu
}

\begin{abstract}
This purpose of this essay is to start a conversation about expanding the focus in education finance to more comprehensively include the problems of educational inheritance and generational tradeoffs as central to education for generational succession. It is based on both long-term personal experience both as a professor, and as school board member and president. Because of my interpretations of this experience, much of the usual citation list is not included. It is deliberately written in the form of a provocative essay, because its emphasis is less about a search for causal prediction and explanation, and more about engagement in policy framing.

This essay has not been created to demonstrate the one best way to succeed. It doesn't even assume some level of certainty is possible. It assumes instead, multiple layers of valid and contradictory meanings. It asks how we should consider looming challenges with both high levels of uncertainty and limited historical precedent. This essay hopes to give these problems greater traction.
\end{abstract}

\section{Keywords}

finance, wicked problems theory, uncertainty theory, generational succession, local and state funding

\section{Introduction}

"Wicked" problems are defined as high stakes problems that are too complex to be measured or solved by traditional causally-focused methods, yet too important to be ignored (Camillis, 2008; Conklin, 2005). Their variables can be deeply interdependent, making it impossible to tease out causality. These are often problems of high levels of importance, containing both high levels of unknown risks and outcomes. Environmental problems can fall in this category. They are problems that are so context dependent, they are unique. 
Another wicked problem is the US legal system. Each case is unique, making causal prediction impossible. Precedent, however, can drive the law forward, one unique case at a time. Political issues can be particularly wicked, especially if they have multiple stakeholders with incommensurable worldviews. For example, those who frame the world as systems of tournaments with winners and losers, may have great difficulty understanding those who frame the world through moral obligations for inclusive human rights.

Roza (2010) took up the issue of wicked problems in education finance, attracting the attention of Bill Gates (2011), who interviewed her in his blog. She argued that multiple sources of funding alone make it impossible to solve problems at a single level of government - local, state, or federal.

Perhaps it is time to start thinking a bit less about levels of governments as useful means to resource fairness, and a little more about governments whose ends include successful generational succession. These generational questions are not only about system efficiency, but also about personal moral worth and consequence. For example, who decides how educational resources flow from one generation to the next? How? Why? Who decides how much is taken in taxes, and from whom? There are, of course, no self-evident responses.

In addressing wicked problems in education finance, it might be useful to examine their implicit endgames. Agreement on a single end would be difficult, so policy issues tend to examine their balances. How many and how much? Is it success in the workforce? Responsible citizenship? Quality of life? Sustainable development? Into this mix, I would like to add successful generational succession. These endgames are a good example of the great problem of wickedness, as there can be no unitary agreement on interpretation, except perhaps temporarily.

Education plays a central role in the problems of generational transitions. Education at all levels (public, private, formal, informal and non-formal), helps prepare the next generation for the increasingly massive tasks of inheriting enormously complex societies. First, education across the sector must help the next generation learn how to contribute to a safe, healthy and in many countries, self-governed, nation. Second, it must help prepare the next generation with economic, political and cultural knowledge, skills and values needed for survival in a technological and globalizing economy with many different spoken languages, cultures and views on education and its access. This is our educational inheritance.

But what happens when we leave out important issues? When rational solutions are good, but not enough? For examples, how can you have a stable workplace, community or society without empathy? Without a moral compass? Without a passion to learn? Can or should these be taught in school? What are the generational consequences of a lack of access to good schools?

And since these wicked problems are defined by high levels of uncertainty and differences in meaning, predictive power fails. Now what? Let's at least start. First, what is wicked, not who. Bottom line: Wicked problems are unique, messy, too complicated and too unpredictable to be solved through traditional methods. They have no long-term solutions. Not everyone agrees on their definitions. But we can map the boundaries of our interpretations of them (Yamamoto \& McClure, 2011). 
Second, what's a silver bullet? It is a colloquial term for the "one best way," most efficient, solution to a problem. Most, if not all the time, wicked problems don't have "one size fits all" silver bullet solutions. Would be nice. Lots of hopeful folks. Can't happen. Third, who wants wickedness? No one. Who's got it? Everyone.

- Maureen to Famous Public Administration Scholar: "Do you use wicked problems in your work?

- Famous Public Administration Scholar (with exasperation): "Maureen, ALL of our problems are wicked."

Welcome to politics. The land of righteous disagreement.

What other education finance problems are wicked? If they are: a) related to policy formulation and implementation; b) have very high levels of uncertainty; c) are very complex and important; and d) have multiple stakeholders with competing interests, chances are they are wicked. For some of us, so what's not included? It therefore makes sense to assume a lot of policy attention would be paid to studying these conditions. We would be wrong.

\section{Challenges to Addressing Wicked Problems in Education Finance}

What's wrong then with our current thinking about education finance reform? Nothing, as long as we are dealing with tame problems that can be generalized and are predictable. Great contributions have been and are being made by many disciplines: social scientists, lawyers, historians and other folks from the humanities. The good news is that education reform and educational finance reform has a big tent with lots of room for interdisciplinary conversations about profoundly important topics that are related to generational succession. Thankfully, there is a wide streak of moral commitment to inclusion in our research, as it can help poor children and the marginalized. This is likely to confuse tournament framers.

The bad news is the way we think about education finance problems too often assumes our problems are designed for oversight that needs to be primarily generically tamable, comparable, complicated, solvable and scalable. This contrasts with wicked generational policy problems that can be instead, embedded in local contexts, temporary and unique. A better balance of the two might be helpful. For example, discussions of local revenues rarely describe the diversity of tax capacities within a district. Within a district, taxpayers and voters can vary widely in their ability to pay. This is often assumed, but less often described.

Reforms can be promoted with reports filled with clear, well-developed intentions. Piles of facts. Tightly controlled logic. Often mathematical. Reformers usually assume others can understand, implement and share their interpretations of problems and consequences. Often with a singlemindedness of purpose. Silver bullets. Shot from the state oversight level.

Good luck with that. You tell school board directors in a small rural district that it is a good thing for them to give up access to their annual "hold harmless" clause in state funding, to help support growing numbers of poor urban children. 
With wicked problems, what is left out or sidelined can become defining. Especially when access to resources is involved. For example, in a historically bad model of strategic planning, educators still passionately cling to a medical model that first diagnoses students' needs, and THEN seeks resources to meet them, (under the assumption they will be or should be available or arriving soon.) What would happen to your household budget if you just bought what you needed, without planning how you would pay for it, under the assumption the resources would just be there or certainly arriving shortly? Huh? Under highly uncertain conditions? When today's economies can be wicked.

\section{What Can We Do?}

What isn't being discussed (that needs to be)? Needs-based planning models assume a growth economy. Or great vision. Or a lot of luck. They chronically ignore the question of what do we do when the money isn't there, and cannot show up anytime soon. Similar planning models with the same tacit assumptions of revenue growth still haunt the halls of state departments of education. (And still fill consultants' coffers.) They tell school personnel to first to do a needs assessment. The institution in charge of fixing things, has designed a mission, and then a vision. The thing to be fixed is blended into its goals and objectives, and then, by golly, time to look for supporting resources.

Scratch that. Party's over. Notice that throughout, taxpayers' support capabilities are assumed? Not smart. This model marginalizes information about who pays, how much, and what are the consequences for those who are struggling and can't pay? Why is this important now? Lots of good reasons. First, uncertainty in the predictability of local, state and federal resources cannot be ignored. Demographics alone are contributing to that uncertainty. Second, much like the traditional disparities of student inequalities, there also can be stunningly diverse tax capabilities and inequalities across taxpayers within local communities. These differences can be repeatedly marginalized in districts' planning and negotiations.

An alternative model is better designed for heavy winds. This is the "What do we have, and what can we do?" approach. This doesn't preclude thinking visionary thinking about what else we would do with more resources. But it does try to hold the fantasy in check.

So, here's our basic problem. How can we define wickedness so we can plan to live with it responsibly? As expected, there are no convergent agreements as to definitions (Camillus, 2008, p. 101). In addition, Rittel, H. W. J., \& Webber, M. M. (1973), and Levin, Cashore, Bernstein, \& Auld (2012) defined much more severe wicked problems, calling them "super wicked." They defined them in four points: (a) time is running out; (b) there is no central authority; (c) those seeking to solve the problem are also causing it; and (d) cognitive bias: players irrationally discount the future. I would like to argue that educational inheritance is a super wicked problem.

First, time is running out as generations grow up and away from support from the formal education sector. Second, there is no global central authority and no appetite for it. Local schools have great value. The US school system is decentralized. Nations with centralized systems still compete with other nations. Third, the current adult generation both drives the education for the next and can't agree on its value. Fourth, education is an investment in a future return, and doesn't have the 
political immediacy of other policy issues. Together they paint a bleak, but still hopeful picture of the future. Better descriptions of local level schools may yield important findings.

Almost all the high-level problems in education finance reflect some of these conditions. In addition, wicked problems are also an important way of thinking about the high levels of uncertainty created by unpredicted, large-scale historical events, like technology and natural disasters. We can try to prepare for them, but there is great uncertainty about their occurrence and their consequences for the future. Because these unpredicted historical events are both rare and unpredictable, they can interfere with the implementation of reforms in multiple ways. (Reformers tend to like uniformity and predictability, but not even the silver bullets of predictability can stop historical randomness.)

\section{Historical Events Impacting Education Finance}

What are some of the unplanned historical events sharing the streams of time currently inhabited by our education finance reforms?

- Race issues have grown more diverse in some states, but not others.

- State economies are increasingly uncertain, as they are affected by the production and consumption of international goods and services.

- Many districts' school budgets are large enough to influence local communities' sustainable development efforts. State departments of education tend to focus on instruction and most, therefore, are unprepared to offer support for economic development, even though it is essential for local sustainability and state revenue.

- The long shadow of demographics will ricochet through multiple aspects of the economy, the polity and the culture for a long time to come. We are already feeling the pension crunch. Many other countries instead face a "youth bulge."

- The Internet economy is shifting the pace of development internationally and increasing our economic and social interdependence.

- In the past, economic recoveries may have been more widely distributed, with a rising tide lifting lots of little boats paying state and local taxes. Since the Great Recession of 200809, however, most of the recovery has been concentrated in a few places, and in a few hands.

- Janus. A US Supreme Court ruling that allows teachers more choice in joining unions.

Where does this all new complexity play out? In the most complex arena in education finance. The local school district. How does it come together with local and county municipalities to support sustainable development? Not well.

We in education finance do state level policy better than others. The unique problems of local education finance, however, can too often be overlooked by both legislatures and courts through well-intentioned efforts for equity and adequacy oversight, applied with the broad brushstrokes of state and federal mandates. Lost in these efforts can be their impact on the quotidian activities of local schools, despite the best efforts of states to acknowledge differences. Yet it is in the quotidian of the local, where these well-intentioned mandates can now crowd out arts, sports, building 
maintenance and teacher salaries. This is not to suggest that all mandates should be revoked; rather, that we need to spend more time better describing the peculiar effects of education finance reform in different local communities. Localism has value. Sustainability rests on school's contributions to local and regional economic, social, cultural and generational development.

For example, how can local districts map different interpretations of their contributions to educational inheritance? To what extent is there local consensus as to what equity means for themselves and others? Students only? Teachers? Parents? Taxpayers? How does or should the state reward successful efforts? Local questions might include, do teachers live in the district and circulate earnings? Or do they leave nightly and subsidize other districts? What types of capital (human, social, cultural) capital, capacities and capabilities do schools contribute to (or remove from) the local economy? How well do local teachers understand local communities? What do they know about the education sector outside of their school building?

What we need are better descriptions about perceptions of the value of and contribution to the entire local education sector to local schools' success (public schools, day care centers, colleges, charters, private and religious schools, etc.). Also included are non-profit and non-formal educational efforts. Most of all we need to better understand the sustainability not only of the public-school project, but also of all the other generational efforts being made to help each child learn, one at a time, how to inherit their very own civilization. Will we simply continue to assume the future will just grow? If schools don't understand their students' educational inheritance, how can they help students build their futures?

State oversight, both important and necessary, may need to make a little more room for acknowledgement of the resourcefulness and resilience found in unique local responses, especially in those states that have been cutting back on local funding. Thankfully, many state-level professional organizations have already stepped up to help, as the Pennsylvania School Boards Association (PBSA) has.

What about those who may be supportive, but who are unable to pick up the growing local tax tab. Locally elected school officials can be caught in the middle, muddling through multiple and competing interpretations of the same reforms; and wherein any win by some, may result in losses to others. Win-win strategies rarely visit the tournaments of resource competition.

\section{Concluding Thoughts}

We all know this and have known this for a long time. State-level departments of education focus on fair distributions of inputs for instruction. Most can't also focus on how local districts contribute to sustainable development in local communities. Well, someone needs to. How do you take state and federal education finance reform efforts and make them work well across wildly diverse local settings? Honestly? You don't. You can't. Can't we just admit it? And give the wickedness of localism a little more value?

This is not a paean to local control. It is instead a call from the hustings. Education has competitors. In some states only small percentages of today's taxpayers have children in many school districts. Political candidates have waved property tax reform (or elimination) in front of voters in some 
states. Even the contract clause in many states' constitutions has garnered a little attention by those fretting about pension funds.

So where can we go with this? First, we should debate the proposition that education finance requires urgent debate about super wicked problems related to educational inheritance and generational succession. How can we acknowledge wickedness in policy formation?

Second, can we stop making silver bullets that won't work? Needs-based planning is a silver bullet that can't work. It is both a privileged and pervasive point of view. It is based on a thin description of stakeholders and their decision contexts. Needs-based planning assumes that the resources required to meet designated needs are either currently available or could be made available. It assumes a top level of priority with funders and expects to win competitions from other policy areas. It doesn't take into account recent shifts in both demographics and economic growth, and their consequences for voting patterns.

Third, would a better model be to include resource costing models that ask -What do we have? What can we do? How can we meet needs as responsibly as we can? How can local districts plan when they don't know either what success costs or WHO the money is coming from (Gates, 2011; Roza, 2010)?

Fourth, the field spends a lot of time in honest quests for explanations. But how can we explain what we can't describe? What education finance knowledge and skills do stakeholders have and use in local districts and communities? How do local faculty, administrators, parents and other community members view resource costing or sustainable costing issues, for example? Do they stick with needs-based planning in the face of increasing revenue uncertainty?

Fifth, we need better descriptive maps of local conditions and analyses of their costs. We can't explain wicked problems in a few variables, no matter how hard we try. Big data might help. We need to know how to orient ourselves in different wicked local contexts, both currently and over time, to avoid implicit discounting. Resource costing models are not new to education finance. Qualitative research is not new to education finance. Mixed use methods of qualitative and quantitative research are not new to education finance. Then why do widespread needs-based costing models continue to ignore revenue constraints until too late in planning and negotiations? After folks are righteous and expectations are set? Let's instead make more room for the value of "thick" descriptions of everyday local conditions (Geertz, 1973).

Sixth, can we start mapping the boundaries of our conversations with our different interpretations, looking for bridging language? Can we begin to give more credit to local difference on the revenue side? We have wildly diverse local districts in each state, each with wicked problems, as well as citizens who vote on candidates and issues for wildly different reasons.

Finally, time is running out. There is no central authority, and thankfully, no strongman to fix it. Those driving today's educational inheritance issues also need to improve them. The biggest obstacle to improvement may be a cognitive cultural (?) bias for the short term. We can't fix it, but we can try to reduce the wickedness so better relationships may be possible. With increased attention on the local, let's start small. 


\section{References}

Camillus, J. C. (2008). Strategy as a wicked problem. Harvard Business Review, 86, 98-106.

Carpenter, W. A. (2000, January). Ten years of silver bullets: Dissenting thoughts on education reform. The Phi Delta Kappan, 81(5), 383-389. Retrieved from https://www.jstor.org/stable/20439669

Conklin, J. (2005). Dialogue mapping: Building shared understanding of wicked problems. Hoboken, NJ: Wiley. Gates, W. (2011, March 1). The wicked problem of school funding [Video file]. Retrieved from https://www.gatesnotes.com/Education/Marguerite-Roza-Education-Funding-Wicked-Problem

Geertz, C. (1989). Works and lives: The anthropologist as author. Stanford, CA: Stanford University Press.

Levin, K., Cashore, B., Bernstein, S., \& Auld, G. (2012). Overcoming the tragedy of super wicked problems: Constraining our future selves to ameliorate global climate change. Policy Sciences, 45, 123-52. doi: 10.1007/s11077-012-9151-0

McClure, M. W. (2014). MOOCS, wicked problems and the liberal arts. The Journal of General Education, 63(4), 269-286. doi: 10.1353/jge.2014.0024

Roza, M. (2010). Educational economics: Where do school funds go? Washington, DC: Urban Institute Press.

Rittel, H. W. J., \& Webber, M. M. (1973). Dilemmas in a general theory of planning. Policy Sciences, 4, $155-69$. doi: $10.1007 / \mathrm{BF} 01405730$

Sen, A. (2001). Development as freedom (2nd ed.). Oxford, UK: Oxford University Press.

Yamamoto, Y. \& McClure, M. W. (2011). How can social cartography help researchers? In J. C. Weidman \& W. J. Jacob, Eds. Beyond the comparative: Advancing theory and its application to practice (153-170).

Rotterdam: Sense Publishers. 